Article

\title{
Blue Light Does Not Affect Fruit Quality or Disease Development on Ripe Blueberry Fruit During Postharvest Cold Storage
}

\author{
Yi-Wen Wang ${ }^{1 \oplus}$, Helaina D. Ludwig ${ }^{2}$, Harald Scherm ${ }^{2}{ }^{\circledR}$, Marc W. van Iersel ${ }^{1} \mathbb{D}$ and \\ Savithri U. Nambeesan ${ }^{1, *}$ \\ 1 Department of Horticulture, University of Georgia, 1111 Miller Plant Sciences, 120 Carlton Street, \\ Athens, GA 30602, USA; yiwen.wang25@uga.edu (Y.-W.W.); mvanier@uga.edu (M.W.v.I.) \\ 2 Department of Plant Pathology, University of Georgia, 2105 Miller Plant Sciences, 120 Carlton Street, \\ Athens, GA 30602, USA; hdcapps@uga.edu (H.D.L.); scherm@uga.edu (H.S.) \\ * Correspondence: sunamb@uga.edu; Fax: +1-(706)-542-0624
}

Received: 21 August 2020; Accepted: 25 September 2020; Published: 30 September 2020

\begin{abstract}
Blueberry fruit are perishable after harvesting due to fruit softening, water loss and susceptibility to pathogens. Light, especially blue light, increases the accumulation of anthocyanins and reduces postharvest decay in some fruits, but the effect of blue light on postharvest fruit quality attributes in blueberries is unknown. In this study, we evaluated the effect of blue light on fruit quality, anthocyanin accumulation and disease development during postharvest cold storage $\left(2{ }^{\circ} \mathrm{C}-4{ }^{\circ} \mathrm{C}\right)$ in two experiments with southern highbush blueberry 'Star' and rabbiteye blueberry 'Alapaha'. Overall, diurnal blue light did not affect postharvest fruit quality attributes, such as visual defects, fruit compression, skin puncture, total soluble solid content and titratable acidity, in the two cultivars compared with their respective controls (diurnal white light or continuous darkness). Further, there was no effect of blue light on fruit color and anthocyanin accumulation. Fruit disease incidence in 'Star' ranged from $19.0 \%$ to $27.3 \%$ after 21 days and in 'Alapaha' from $44.9 \%$ to $56.2 \%$ after 24 days in postharvest storage, followed by 4 days at room temperature, but blue light had no consistent effect on postharvest disease incidence for either cultivar. Disease progression following artificial inoculations with Alternaria tenuissima and Colletotrichum acutatum in 'Star' was not influenced by light treatment prior to inoculation and during fruit storage. In a separate experiment, we tested the effect of blue light on color development in 'Farthing', a southern highbush blueberry cultivar with fruit prone to non-uniform ripening, whereby the stem-end remains green as the rest of the fruit turns blue. Although green stem-end spots turned blue over time, there was no statistically significant effect of the blue light treatment. Overall, these data indicate that blue light does not affect fruit quality attributes or disease development in ripe blueberry fruit during postharvest storage in the conditions investigated here.
\end{abstract}

Keywords: fruit texture; shelf-life; storability; Vaccinium corymbosum; Vaccinium virgatum

\section{Introduction}

Blueberries are native to North America, with the United States being the largest producer, accounting for almost half of the global production [1]. Currently, the commercially important species cultivated in the northern parts of the United States include lowbush (Vaccinium angustifolium Ait.) and northern highbush blueberries (V. corymbosum L.). In the southeastern states, the main cultivated species include rabbiteye ( $V$. virgatum Ait.) and southern highbush blueberries (hybrids of $V$. corymbosum, V. virgatum and V. darrowii Camp.) [2,3]. Blueberries are considered "super fruits", having a high 
antioxidant and nutraceutical capacity [4]. Some of the health benefits associated with consuming blueberry fruit include decreased cardiovascular risk, improved cognitive performance and a decrease in aging-related damage $[5,6]$.

After harvest, blueberries have a shelf-life of 1 to 8 weeks depending on the genotype, method of harvest and storage regime [7-9]. The decrease in fruit quality during postharvest storage is mainly due to loss of fruit firmness, shriveling due to water loss and decay caused by postharvest pathogens [10-12]. Currently, pre-harvest fungicide treatments are used to prevent postharvest pathogen-induced decay [13]. Other potential postharvest treatments to prolong shelf-life and reduce fungal growth include natural edible coatings such as chitosan, as well as irradiation $[7,9,14-17]$.

The effect of light quality and quantity on postharvest shelf-life of fruits and vegetables is well documented. For example, ultraviolet (UV) light has sterilizing benefits on fresh produce, thus extending shelf-life [18]. This is also true for light in the visible range [19,20]. For example, exposure to low light intensity can delay senescence and improve postharvest storage in basil, lettuce and spinach compared with storage in complete darkness. Low light intensity retarded the degradation of pigments such as chlorophyll and carotenoids, increased ATP levels and reduced senescence-associated symptoms [21-23].

Some of the common lighting sources that are traditionally used include high-pressure sodium, incandescent and fluorescent lamps. However, currently light-emitting diodes (LEDs) offer several advantages in greenhouse production and food preservation [24,25]. They offer high emissions of monochromatic light and therefore can provide light with a narrow bandwidth $[25,26]$. LEDs can be placed close to the produce, since they emit little radiant heat and may have a minimal heating effect $[24,26]$. This can allow for the use of LEDs in combination with cold storage methods. Other benefits are long life expectancies and compactness in the design of LED lights. The increasing efficiency of LEDs makes them attractive for adoption by the food industry.

Blue light (380 to $500 \mathrm{~nm}$ ) from LED lighting has especially been shown to increase the accumulation of certain secondary metabolites such as pigments and glucosinolates [27]. In strawberries (Fragaria $\times$ ananassa), grapes (Vitis spp.) and bilberries (Vaccinium myrtillus), blue light can increase anthocyanin production by enhancing the activity of anthocyanin metabolism-related enzymes [20,28,29]. Further, blue light can inhibit the growth of certain pathogens. For example, blue light irradiation inhibited the development of the gray mold pathogen Botrytis cinerea in tomato and grape leaves by increasing proline and antimicrobial metabolite content, as well as defense response gene expression [30,31]. In fruits such as citrus, blue light suppressed mycelial growth by the postharvest fungi Penicillium digitatum, P. italicum and $P$. citri. The inhibition of fungal growth by blue light could be a direct effect of inhibiting mycelial growth, suppression of activity of fungal polygalacturonase or increased host defense responses [32-35].

The effect of blue light has not been tested previously on blueberry fruit quality during storage. The main objective of this study was to evaluate the effects of blue light on fruit quality characteristics of blueberries during postharvest storage. Hence, we evaluated the effect of blue light produced by LEDs on blueberry fruit quality, anthocyanin accumulation and disease development during postharvest cold storage.

\section{Materials and Methods}

\subsection{Fruit Collection and LED Light Source}

Ripe blueberries for this study were obtained from three cultivars, 'Star', 'Farthing' and 'Alapaha', from commercial farms in southern Georgia between May and June 2017, with the former two (southern highbush) being hand-harvested and the latter (rabbiteye) being machine-harvested. Harvested fruit were packed into clamshells and transported back to the University of Georgia, Athens, stored overnight in a cold room $\left(2{ }^{\circ} \mathrm{C}\right.$ to $\left.4{ }^{\circ} \mathrm{C}\right)$, re-sorted for uniformity and arranged in a monolayer on an aluminum pan prior to light treatment.

The blue light source consisted of flexible LED strips (5630 blue LEDs, BZONE International, Taipei, Taiwan) with a peak wavelength of $\sim 430 \mathrm{~nm}$ at an intensity of $40 \mu \mathrm{mol} \mathrm{m}{ }^{-2} \mathrm{~s}^{-1}$. White light 
was also provided, using flexible LED strips (Pure white 5630 LEDs, Favolcano, Fuzhou, China). The distance between the light source and fruit-holding pan was $\sim 8 \mathrm{~cm}$.

\subsection{Fruit Quality Attributes}

Two experiments were conducted with 'Star' and 'Alapaha' fruit. For each experiment, a 12-shelf light rack $(54 \times 45 \times 137 \mathrm{~cm})$ was set up in a walk-in cooler maintained at $2{ }^{\circ} \mathrm{C}-4{ }^{\circ} \mathrm{C}$ under high humidity. Each shelf was assigned randomly to one of three light treatments in four replicates (blocks). Each replicate contained three aluminum pans, each with 100 fruit for each of three postharvest time points. The three light treatments used in this study included alternating 12-h blue light/12-h dark cycle (referred to as "blue" henceforth) along with two controls: alternating 12-h white light/12-h dark cycle (referred to as "white" henceforth) and continuous dark (Figure S1). The rack was covered with black plastic sheets to prevent interference among the three light regimes. The experimental design was a randomized complete block with three light treatments, four replicates (blocks) and three postharvest storage periods.

For each cultivar, an initial fruit quality analysis was performed at day 0 (prior to light treatment); subsequent measurements were taken at 4,15 and 21 days of treatment for 'Star' and at 4, 16 and 24 days of treatment for 'Alapaha'. At each time point, fruit from a single aluminum pan per replicate was used for quality assessment. Fruit quality attributes assessed included visual assessment, measurements of texture, weight, titratable acidity (TA), total soluble solid (TSS) content, total anthocyanins and color, as described in detail in Nambeesan et al. [15]. Briefly, for visual assessment, 30 berries per replicate were examined and scored for symptoms of bruising such as tears, juice leakiness, dents or signs of mold and expressed as a percentage of defect-free fruit. Fruit texture, compression and skin puncture force were quantified using a fruit texture analyzer (GS-15, Güss Manufacturing, Strand, South Africa) on 12 berries per replicate. Fruit weight was measured on 20 individual berries per replicate using an electronic balance (Quintix Precision Balance, Sartorius, Bohemia, NY). For measurement of TA, TSS and anthocyanins, juice from $\sim 40 \mathrm{~g}$ of fruit was extracted using a household blender. The juice was centrifuged with a benchtop centrifuge (Allegra X-22, Beckman Coulter Life Sciences, Indianapolis, IN) for $10 \mathrm{~min}$ at $3901 \mathrm{~g}$. The resulting supernatant was filtered using cheesecloth. TSS and TA measurements were performed as described in Nambeesan et al. [15]. Total anthocyanins were determined according to Lee et al. [36]. Briefly, $0.5 \mathrm{~mL}$ of supernatant from the blueberry juice was mixed with two buffers; (1) $2 \mathrm{~mL}$ of $0.025 \mathrm{M}$ potassium chloride, $\mathrm{pH} 1.0$ and (2) $2 \mathrm{~mL}$ of $0.4 \mathrm{M}$ sodium acetate, $\mathrm{pH}$ 4.5. The absorbance was measured at 520 and $700 \mathrm{~nm}$ using a spectrophotometer (GENESYS 10S UV-Vis, Thermo Fisher Scientific, Waltham, MA), and anthocyanin concentrations were calculated as cyanidin-3-glucosides equivalents using the equation in Lee et al. [36]. Fruit color was determined using a colorimeter (3nh Technology Co., Shenzhen, China) on 20 berries from each replication. Two measurements were made on the fruit surface, around the equatorial region on opposite ends. Statistical analysis (one-way analysis of variance for a randomized complete block design) was performed separately for each time point after treatment within a cultivar using JMP Pro 12 (SAS Institute, Cary, NC, USA). Means were separated using Tukey's Honest Significant Difference (HSD) test $(\alpha=0.05)$.

\subsection{Natural Postharvest Disease During Storage}

Natural postharvest disease development was assessed in the two experiments described above. Fruit samples ( $\sim 60$ berries per replicate) for disease assessment were removed from postharvest storage after 4, 15 and 21 days of treatment for 'Star' and after 4,16 and 24 days of treatment for 'Alapaha'. Fruit were then incubated at room temperature for another 4 days to allow infections that occurred during postharvest storage to develop [11]. For each assessment date and replicate, the total number of berries with symptoms and/or signs of postharvest decay was counted, and these data were used to calculate postharvest disease incidence (percentage of fruit affected). Disease incidence over time was used to calculate areas under the disease progress curve (AUDPC) in units of percent-days [37]. If fruit showed 
signs and symptoms of disease development, then fungal pathogens were identified macroscopically and microscopically [38,39]. Final disease incidence and AUDPC values among treatments were subjected to analysis of variance and means separation, as described for fruit quality above.

\subsection{Postharvest Disease Progression Following Artificial Inoculation}

Two experiments were conducted with 'Star' and 'Alapaha' fruit from the same harvests described above. For each experiment, fruit were again arranged in a separate 12-shelf light rack in a walk-in cooler at $2{ }^{\circ} \mathrm{C}-4{ }^{\circ} \mathrm{C}$ under high humidity, and each shelf was assigned randomly to one of the three light treatments in four blocks. Artificial inoculation experiments were performed with one isolate each of Alternaria tenuissima and Colletotrichum acutatum, two common postharvest pathogens in blueberries. After being held for 4 days in the cold-storage light treatments described above, each fruit was inoculated with a $20-\mu \mathrm{L}$ drop of a spore suspension $\left(1 \times 10^{5}\right.$ conidia per $\left.\mathrm{mL}\right)$ on the stem end with one of the above pathogens; fruit mock-inoculated with a $20-\mu \mathrm{L}$ drop of water served as controls. Inoculated fruit were separated by pathogen into different aluminum pans, kept on moist filter paper at $23^{\circ} \mathrm{C}-25^{\circ} \mathrm{C}$ for $24 \mathrm{~h}$, and placed under the aforementioned three light treatments at $2{ }^{\circ} \mathrm{C}-4{ }^{\circ} \mathrm{C}$ for 9 days. Fruit were maintained for another 4 days at $23^{\circ} \mathrm{C}-25^{\circ} \mathrm{C}$ under ambient light in 'Star' and the three light regimes in 'Alapaha', after removal from cold storage. Disease incidence was recorded separately for each pathogen from 50 berries per replicate [39,40]. Analysis of variance and means separation on disease incidence values were conducted as described above.

\subsection{Progression of Color Development on Stem-End Green Spots}

'Farthing' southern highbush blueberry fruit is often affected by uneven ripening, whereby the stem-end remains green with the remainder of the fruit turning fully blue. Hand-harvested 'Farthing' fruit at the ripe stage but retaining a green spot at the stem end were subjected to the three light treatments described above during cold storage $\left(2{ }^{\circ} \mathrm{C}-4{ }^{\circ} \mathrm{C}\right)$ to determine the effect of blue light on improvement of color development. Each experimental unit consisted of 27-30 berries placed in a monolayer in a polystyrene Petri dish bottom with the green-spotted stem ends facing the light source. There were five replicates for each treatment. Berries (in Petri dishes) were removed after 0, 4, 8 and 11 days of treatment for analysis of color progression at the stem end by image analysis and placed back in the cold room after analysis at every time point. Each Petri dish replicate was imaged with a digital camera (Canon PowerShot A640, Tokyo, Japan), and images were analyzed using ImageJ software (National Institutes of Health, Rockville, MD, USA) to quantify the green-to-blue color transition under the three light treatments. For each image, the analysis yielded a grayscale value on a scale from 0 (black) to 255 (white), with a lower value indicating more blue. Analysis of variance and means separation on grayscale values were conducted as described above.

\section{Results}

\subsection{Fruit Quality Attributes}

Blue light did not affect the development of visual defects such as bruising and leakiness of blueberry fruit during storage (Figure 1). Prior to treatment, the percentage of defect-free fruit was 91.7\% for 'Star' and $97.5 \%$ for 'Alapaha'. Subsequently, across all light treatments combined, the average decline in sound fruit was slower for 'Star' ( $88.1 \%, 82.8 \%$ and $80.6 \%$ after 4,15 and 21 days, respectively) than for 'Alapaha' (73.3\%, 24.2\% and 20.3\% after 4, 14 and 24 days, respectively) (Figure 1). 

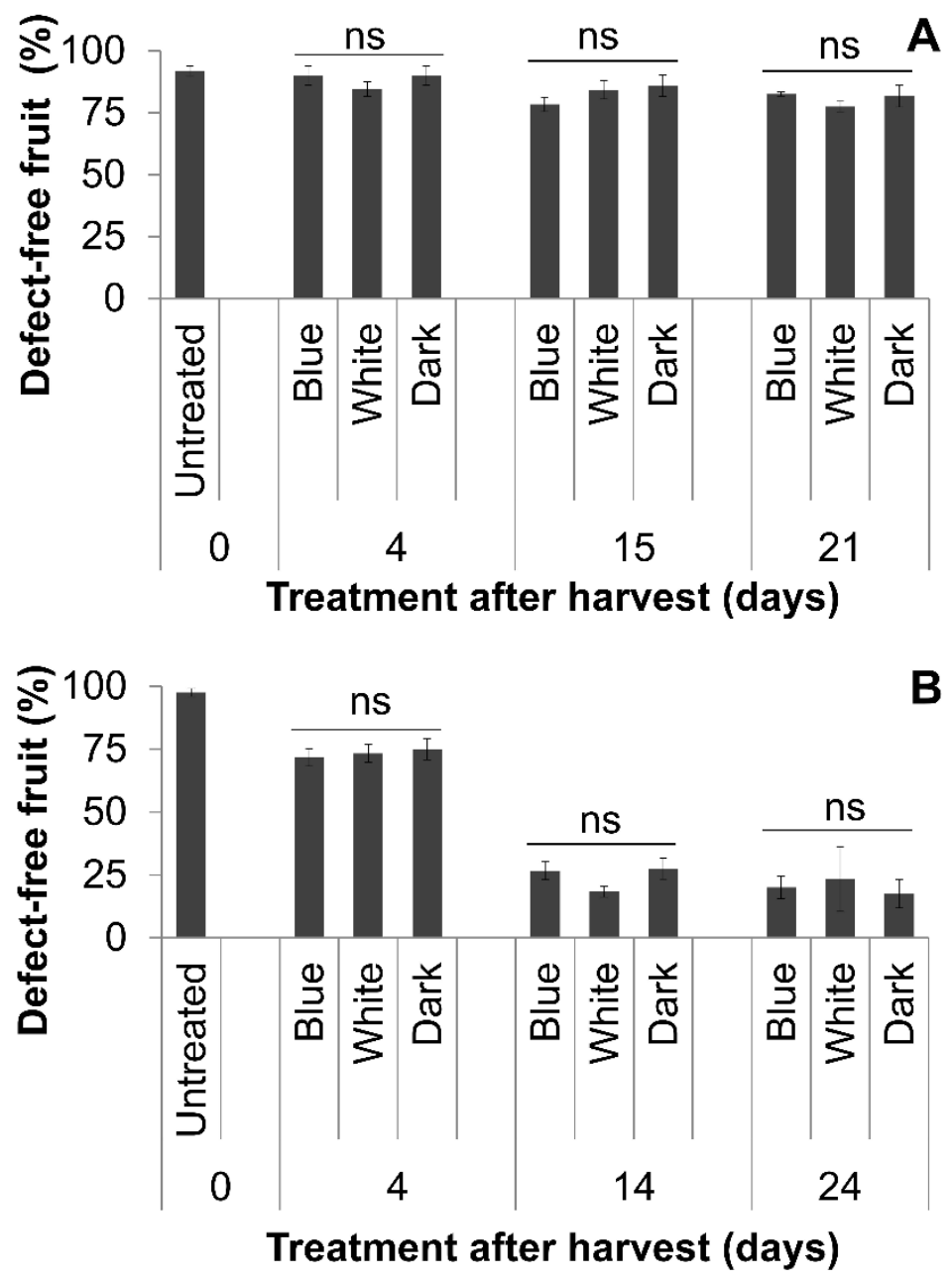

Figure 1. Percentage of defect-free fruit under different light treatments in ripe 'Star' (A) and 'Alapaha' (B) blueberries in cold storage. An initial fruit quality assessment was performed prior to treatment initiation (day 0). One-way analysis of variance was performed between the three treatments (blue, white and dark) separately for each time point after treatment. ns $=$ non-significant $(\alpha=0.05)$.

During storage, 'Star' fruit had higher compression and skin puncture values than 'Alapaha' fruit. Treatment with blue light, compared with the controls, did not affect fruit compression and skin puncture values at any time point, nor was fruit weight affected consistently (Tables 1 and 2). TSS content was generally not affected by the light treatments, except for 'Star' which had higher TSS by $6.3 \%$ and $7.2 \%$ under white light treatment compared with dark and blue light treatment, respectively, at 4 days of treatment (Table 1). TA was similar in all treatments except in 'Alapaha', which had slightly lower TA under blue light compared with dark treatment, but only at 14 days after treatment (Table 2). Fruit $\mathrm{pH}$ was generally not significantly different among treatments except for 'Star' where $\mathrm{pH}$ was lower under blue and white light treatments compared with dark at 15 days of treatment (Table 1). 
Table 1. Quality attributes of ripe 'Star' southern highbush blueberries subjected to light treatments at various times during cold storage.

\begin{tabular}{|c|c|c|c|c|c|c|c|}
\hline $\begin{array}{l}\text { Days after } \\
\text { Treatment }\end{array}$ & Treatment & $\begin{array}{l}\text { Compression } \\
(\mathrm{kg})\end{array}$ & $\begin{array}{l}\text { Puncture } \\
\text { (kg) }\end{array}$ & $\begin{array}{l}\text { Weight } \\
\text { (g) }\end{array}$ & $\begin{array}{l}\text { TSS }^{a} \\
\left({ }^{\circ} \text { Brix }\right)\end{array}$ & $\begin{array}{c}\mathrm{TA}^{\mathrm{b}} \\
(\%)\end{array}$ & $\mathrm{pH}$ \\
\hline 0 & - & 0.23 & 0.13 & 2.07 & 13.4 & 0.58 & 3.43 \\
\hline \multirow[t]{4}{*}{4} & Blue & 0.24 & 0.14 & 2.11 & $13.1 \mathrm{~b}$ & 0.55 & 3.35 \\
\hline & White & 0.23 & 0.14 & 2.14 & $14.1 \mathrm{a}$ & 0.41 & 3.53 \\
\hline & Dark & 0.24 & 0.14 & 2.28 & $13.2 \mathrm{~b}$ & 0.52 & 3.40 \\
\hline & Prob $>F$ & ns & ns & ns & 0.0134 & ns & $\mathrm{ns}$ \\
\hline \multirow[t]{4}{*}{15} & Blue & 0.27 & 0.13 & $2.17 \mathrm{ab}$ & 13.4 & 0.40 & $3.50 \mathrm{~b}$ \\
\hline & White & 0.25 & 0.12 & $2.02 \mathrm{~b}$ & 13.5 & 0.42 & $3.50 \mathrm{~b}$ \\
\hline & Dark & 0.27 & 0.12 & $2.20 \mathrm{a}$ & 13.3 & 0.40 & $3.68 \mathrm{a}$ \\
\hline & Prob $>F$ & ns & ns & 0.0263 & ns & ns & 0.0282 \\
\hline \multirow[t]{4}{*}{21} & Blue & 0.27 & 0.11 & 2.08 & 13.0 & 0.39 & 3.63 \\
\hline & White & 0.27 & 0.11 & 2.00 & 13.1 & 0.37 & 3.68 \\
\hline & Dark & 0.28 & 0.12 & 2.11 & 12.7 & 0.41 & 3.53 \\
\hline & Prob $>F$ & ns & ns & ns & ns & ns & ns \\
\hline
\end{tabular}

Means for a given treatment time followed by the same letter are not significantly different from each other $(\alpha=0.05)$. ns = non-significant. ${ }^{\text {a }}$ Total soluble solids (TSS) ${ }^{\text {b }}$ Titratable acidity (TA).

Table 2. Quality attributes of ripe 'Alapaha' rabbiteye blueberries subjected to light treatments at various times during cold storage.

\begin{tabular}{|c|c|c|c|c|c|c|c|}
\hline $\begin{array}{l}\text { Days after } \\
\text { Treatment }\end{array}$ & Treatment & $\begin{array}{l}\text { Compression } \\
(\mathrm{kg})\end{array}$ & $\begin{array}{l}\text { Puncture } \\
\text { (kg) }\end{array}$ & $\begin{array}{c}\text { Weight } \\
\text { (g) }\end{array}$ & $\begin{array}{l}\text { TSS a } \\
\left({ }^{\circ} \text { Brix) }\right.\end{array}$ & $\mathrm{TA}^{\mathrm{b}}(\%)$ & $\mathrm{pH}$ \\
\hline 0 & - & 0.15 & 0.11 & 1.13 & 14.0 & 0.41 & 3.30 \\
\hline \multirow[t]{4}{*}{4} & Blue & 0.15 & 0.10 & 1.08 & 14.0 & 0.35 & 3.33 \\
\hline & White & 0.15 & 0.10 & 1.16 & 14.2 & 0.36 & 3.35 \\
\hline & Dark & 0.16 & 0.10 & 1.08 & 13.7 & 0.37 & 3.38 \\
\hline & Prob $>F$ & ns & ns & ns & ns & ns & ns \\
\hline \multirow[t]{4}{*}{14} & Blue & 0.13 & 0.10 & 1.14 & 14.1 & $0.292 \mathrm{~b}$ & 3.58 \\
\hline & White & 0.15 & 0.11 & 1.06 & 14.2 & $0.295 \mathrm{ab}$ & 3.63 \\
\hline & Dark & 0.15 & 0.11 & 1.10 & 14.1 & $0.298 \mathrm{a}$ & 3.75 \\
\hline & Prob $>F$ & ns & ns & ns & ns & 0.0415 & ns \\
\hline \multirow[t]{4}{*}{24} & Blue & 0.16 & 0.11 & 1.10 & 13.8 & 0.28 & 3.53 \\
\hline & White & 0.17 & 0.12 & 1.13 & 13.9 & 0.27 & 3.48 \\
\hline & Dark & 0.17 & 0.11 & 1.05 & 13.7 & 0.29 & 3.48 \\
\hline & Prob $>F$ & ns & ns & ns & ns & ns & ns \\
\hline
\end{tabular}

Means for a given treatment time followed by the same letter are not significantly different from each other $(\alpha=0.05)$. ns $=$ non-significant. ${ }^{\text {a }}$ Total soluble solids (TSS) ${ }^{\text {b }}$ Titratable acidity (TA).

\subsection{Fruit Color and Anthocyanin}

Blue light did not affect fruit anthocyanin content in either cultivar tested (Figure 2). With regard to fruit color-related parameters, the parameter $L^{*}$ that measures lightness was lower under white compared with blue light treatment at 4 days of treatment in 'Star', indicating darker fruit (Table 3). The $\mathrm{a}^{*}$ value (red/green) was lower (greener) under blue light compared with the dark treatment in 'Alapaha' at 14 days of treatment (Table 4). At all other time points during treatment, no significant differences were observed in 'Alapaha' and 'Star' (Tables 3 and 4). 

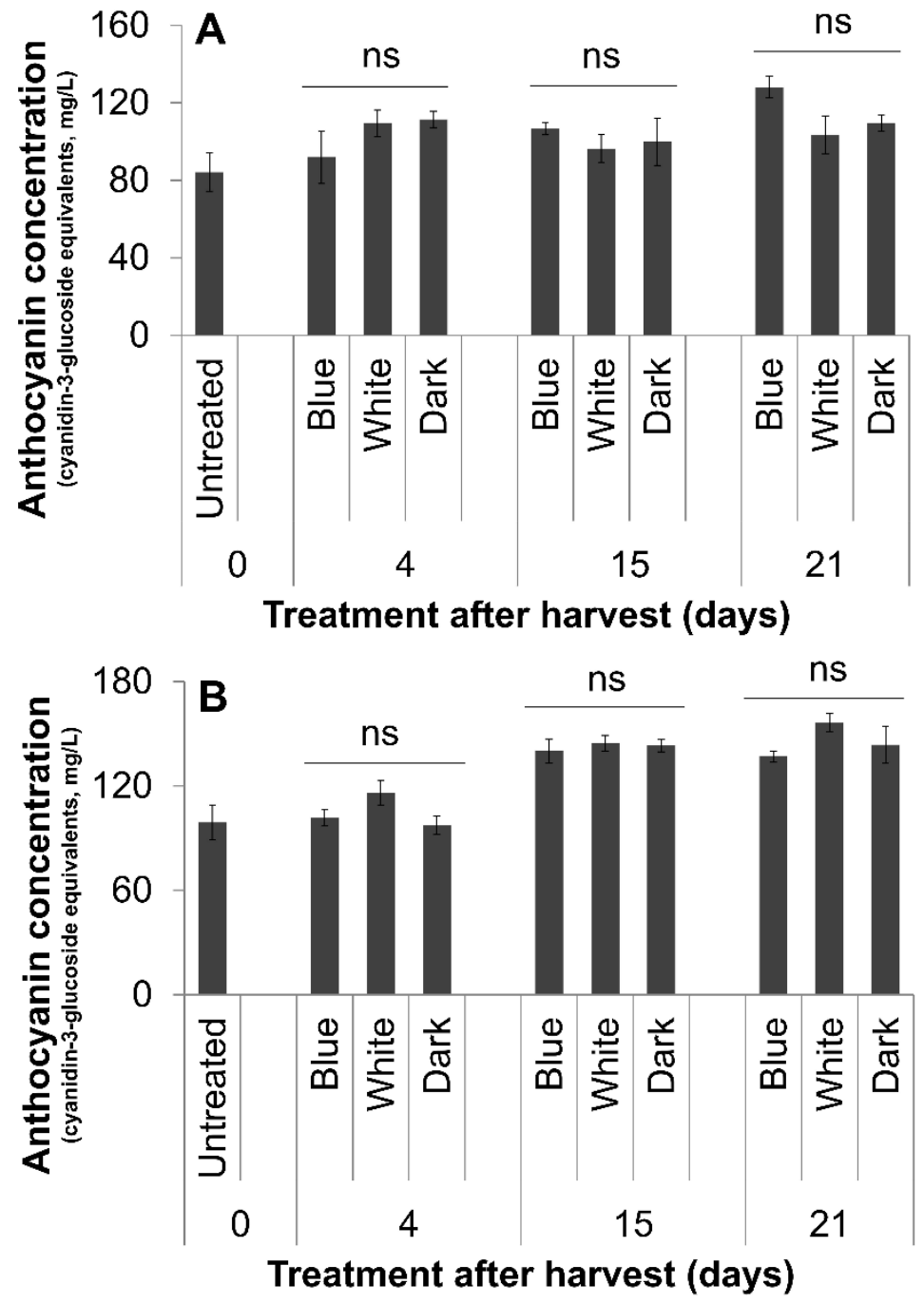

Figure 2. Anthocyanin concentration (expressed as cyanidin-3-glucoside equivalents) under different light treatments in ripe 'Star' (A) and 'Alapaha' (B) blueberries in cold storage. An initial fruit quality assessment was performed prior to treatment initiation (day 0 ). One-way analysis of variance was performed between the three treatments (blue, white and dark) separately for each time point after treatment. $\mathrm{ns}=$ non-significant $(\alpha=0.05)$. 
Table 3. Color values in ripe 'Star' southern highbush blueberries subjected to light treatments at various times during cold storage.

\begin{tabular}{ccccccc}
\hline $\begin{array}{c}\text { Days after } \\
\text { Treatment }\end{array}$ & Treatment & $\mathbf{L}^{*}$ & $\mathbf{a}^{*}$ & $\mathbf{b}^{*}$ & $\mathbf{c}^{*}$ & $\mathbf{h}^{*}$ \\
\hline 0 & - & 29.37 & -0.72 & -3.60 & 3.71 & 258.71 \\
\hline \multirow{4}{*}{4} & Blue & $30.23 \mathrm{a}$ & -0.87 & -4.01 & 4.12 & 258.52 \\
& White & $29.15 \mathrm{~b}$ & -0.64 & -3.44 & 3.55 & 261.12 \\
& Dark & $30.19 \mathrm{ab}$ & -0.90 & -4.05 & 4.16 & 257.92 \\
& Prob $>F$ & 0.0269 & $\mathrm{~ns}$ & $\mathrm{~ns}$ & $\mathrm{~ns}$ & $\mathrm{~ns}$ \\
\hline \multirow{4}{*}{15} & Blue & 30.66 & -0.89 & -4.24 & 4.40 & 257.35 \\
& White & 29.79 & -0.65 & -3.86 & 4.07 & 258.62 \\
& Dark & 30.27 & -0.81 & -3.92 & 4.04 & 260.90 \\
& Prob $>F$ & $\mathrm{~ns}$ & $\mathrm{~ns}$ & $\mathrm{~ns}$ & $\mathrm{~ns}$ & $\mathrm{~ns}$ \\
\hline \multirow{2}{*}{21} & Blue & 30.41 & -1.00 & -4.37 & 4.50 & 257.78 \\
& White & 30.07 & -1.03 & -4.22 & 4.36 & 256.47 \\
& Dark & 30.69 & -1.04 & -4.32 & 4.47 & 255.43 \\
& Prob $>F$ & $\mathrm{~ns}$ & $\mathrm{~ns}$ & $\mathrm{~ns}$ & $\mathrm{~ns}$ & $\mathrm{~ns}$ \\
\hline
\end{tabular}

Means for a given treatment time followed by the same letter are not significantly different from each other $(\alpha=0.05)$. ns $=$ non-significant.

Table 4. Color values in ripe 'Alapaha' rabbiteye blueberries subjected to light treatments at various times during cold storage.

\begin{tabular}{ccccccc}
\hline $\begin{array}{c}\text { Days after } \\
\text { Treatment }\end{array}$ & Treatment & $\mathbf{L}^{*}$ & $\mathbf{a}^{*}$ & $\mathbf{b}^{*}$ & $\mathbf{c}^{*}$ & $\mathbf{h}^{*}$ \\
\hline 0 & - & 29.35 & -0.92 & -3.7 & 3.83 & 256.57 \\
\hline \multirow{4}{*}{4} & Blue & 29.56 & -0.97 & -3.41 & 3.57 & 255.08 \\
& White & 29.59 & -0.90 & -3.28 & 3.41 & 255.13 \\
& Dark & 29.42 & -0.93 & -3.36 & 3.50 & 255.28 \\
& Prob $>F$ & ns & ns & ns & ns & ns \\
\hline \multirow{4}{*}{14} & Blue & 27.97 & $-0.79 \mathrm{~b}$ & -3.08 & 3.27 & 253.69 \\
& White & 28.35 & $-0.58 \mathrm{ab}$ & -2.83 & 2.96 & 259.74 \\
& Dark & 27.85 & $-0.42 \mathrm{a}$ & -2.74 & 2.87 & 261.24 \\
& Prob $>F$ & $\mathrm{~ns}$ & 0.0398 & $\mathrm{~ns}$ & $\mathrm{~ns}$ & $\mathrm{~ns}$ \\
\hline \multirow{2}{*}{24} & Blue & 29.02 & -0.72 & -2.95 & 3.11 & 255.15 \\
& White & 29.43 & -0.89 & -3.25 & 3.39 & 254.59 \\
& Dark & 28.84 & -0.58 & -2.55 & 2.83 & 256.67 \\
& Prob $>F$ & ns & ns & ns & ns & ns
\end{tabular}

Means for a given treatment time followed by the same letter are not significantly different from each other $(\alpha=0.05)$. ns $=$ non-significant.

\subsection{Natural Postharvest Disease During Storage}

Based on macroscopic and microscopic examination, Alternaria, Botrytis and Colletotrichum spp. causing anthracnose fruit rots were the most common naturally occurring postharvest pathogens in both cultivars. Overall fruit disease incidence at the end of the experiment ranged from $19.0 \%$ to $27.3 \%$ in 'Star' and $44.9 \%$ to $56.2 \%$ in 'Alapaha' (Table 5). In general, there was no significant effect of light treatment on final disease incidence or AUDPC (Table 5), with the exception of AUDPC for 'Star' where cumulative values during the postharvest period were higher for blue light than for white light or darkness $(p=0.02)$. 
Table 5. Natural postharvest disease incidence (percentage of affected fruit) and cumulative development of disease incidence (expressed as area under the disease progress curve, AUDPC) in ripe 'Star' and 'Alapaha' blueberries under three light treatments for postharvest storage periods of 21 and 24 days for 'Star' and 'Alapaha', respectively, followed by another 4 days at room temperature at ambient light.

\begin{tabular}{ccccc}
\hline & \multicolumn{2}{c}{ 'Star' } & \multicolumn{2}{c}{ 'Alapaha' } \\
\cline { 2 - 5 } Treatment & $\begin{array}{c}\text { Final Disease } \\
\text { Incidence (\%) }\end{array}$ & $\begin{array}{c}\text { AUDPC } \\
\text { (\%-Days) }\end{array}$ & $\begin{array}{c}\text { Final Disease } \\
\text { Incidence (\%) }\end{array}$ & $\begin{array}{c}\text { AUDPC } \\
\text { (\%-Days) }\end{array}$ \\
\hline Blue & 27.3 & $343.5 \mathrm{a}$ & 51.9 & 591.5 \\
White & 19.0 & $201.5 \mathrm{~b}$ & 44.9 & 656.5 \\
Dark & 21.0 & $222.1 \mathrm{~b}$ & 56.2 & 558.3 \\
Prob $>F$ & $\mathrm{~ns}$ & 0.0204 & $\mathrm{~ns}$ & $\mathrm{~ns}$ \\
\hline
\end{tabular}

Means within a column followed by the same letter are not significantly different from each other $(\alpha=0.05)$. ns $=$ non-significant.

\subsection{Postharvest Disease Progression Following Artificial Inoculation}

Artificial inoculations with A. tenuissima and C. acutatum performed on 'Star' berries yielded consistent fruit disease development, whereas they did not for 'Alapaha'; hence, only data for 'Star' were analyzed further. Mean postharvest fruit disease incidence among four replicates varied from $66.3 \%$ to $77.5 \%$ for Alternaria and from $53.4 \%$ to $74.8 \%$ for Colletotrichum (Figure 3). However, disease incidence following inoculation was not influenced by light treatment prior to inoculation and during fruit storage ( $p=0.2386$ and 0.1636 for the two pathogens, respectively).

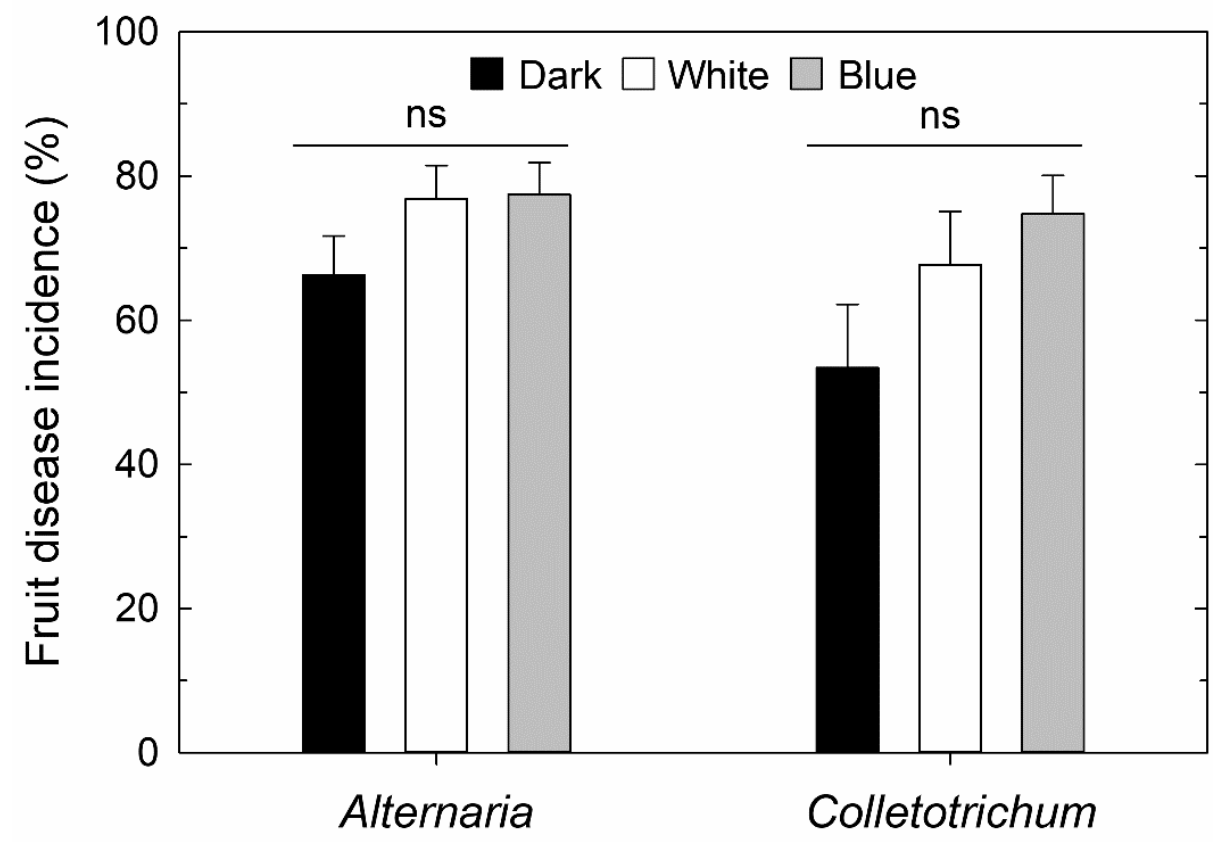

Figure 3. Postharvest disease incidence (percentage of affected fruit) in ripe 'Star' southern highbush blueberry fruit inoculated with Alternaria tenuissima and Colletotrichum acutatum under three light treatments in cold storage. Fruit were incubated under the light treatments for 4 days prior to inoculation and 9 days after inoculation, followed by another 4 days at room temperature under ambient light. Values are means and standard errors of four replicate groups of fruit per treatment. One-way analysis of variance was performed between the three treatments (blue, white and dark) separately for each pathogen. Differences were non-significant $(\alpha=0.05)$. 


\subsection{Progression of Color Development on Stem-End Green Spots}

The grayscale values of the green stem-end spots on 'Farthing' fruit, as determined by image analysis of photographs taken at $0,4,8$ and 11 days of exposure to the three light treatments, decreased over time, documenting that the green spots became more blue (Figure 4; Figure S2). There was no difference in the change in color among the dark, white and blue light treatments.

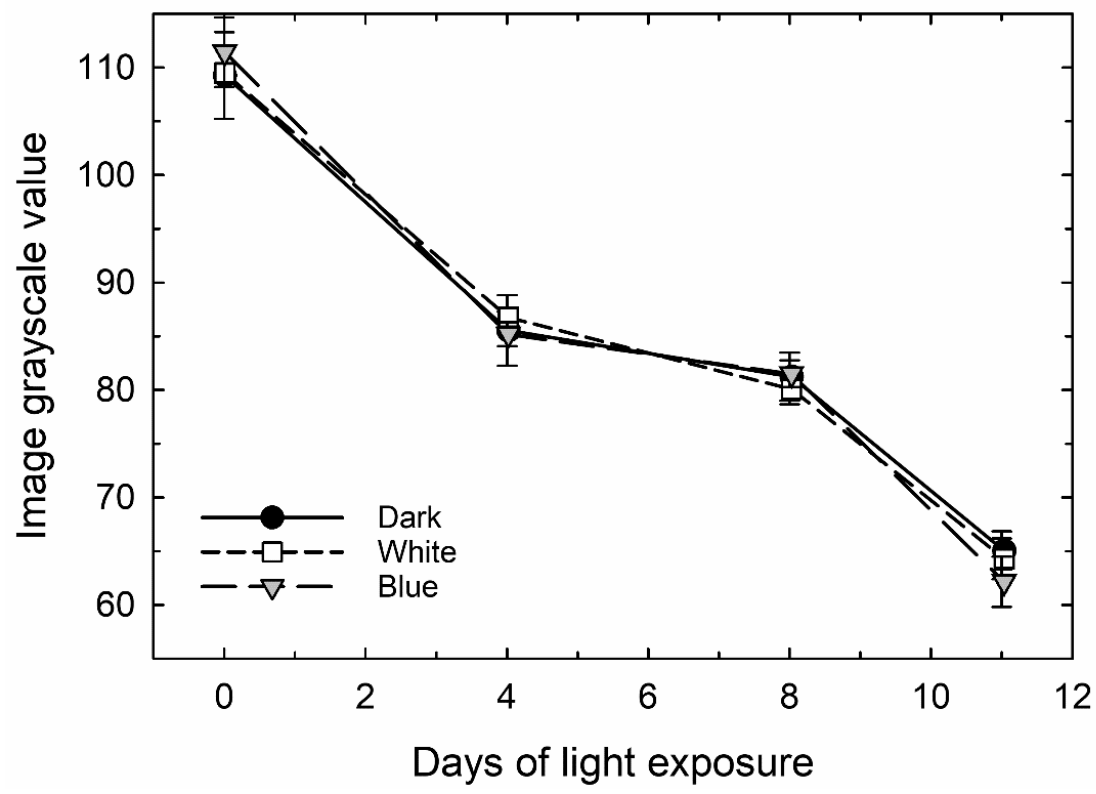

Figure 4. Ripening of green stem-end spots on mature 'Farthing' southern highbush blueberries under three light treatments in cold storage. Image analysis grayscale values are scaled between 0 (black) and 255 (white); hence, the lower the value, the more blue the spot on the berries. Values are means and standard errors of five replicate groups of berries per treatment. One-way analysis of variance was performed between the three treatments (blue, white and dark). Differences were non-significant $(\alpha=0.05)$ at the times after exposure when measurements were performed.

\section{Discussion}

Multiple studies have demonstrated the effect of light on delaying senescence and extending shelf-life in green leafy vegetables [21-23,41]. In lettuce, blue light increased vitamin C and polyphenolic content during storage without affecting $\mathrm{pH}$ and moisture content [42]. Additionally, blue light promoted anthocyanin accumulation, delayed pathogen growth and prolonged shelf-life in certain fruits [20,28,29,32,35,43-45]. In our study, blue light did not consistently affect postharvest fruit storage attributes, which included visual quality, fruit softening, skin toughness, TSS content, TA and weight, compared with dark and white light treatments. Mature green tomatoes treated with $85.7 \mu \mathrm{mol} \mathrm{m} \mathrm{m}^{-2} \mathrm{~s}^{-1}$ of blue light ripened more slowly and had increased firmness during postharvest storage without changes in TSS content [46]. The increase in firmness may have been an effect of delayed ripening rather than a direct effect of light treatment. In another study, strawberries treated with $40 \mu \mathrm{mol} \mathrm{m}{ }^{-2} \mathrm{~s}^{-1}$ blue light for 12 days at $5{ }^{\circ} \mathrm{C}$ showed an increase in rate of respiration, ethylene content, antioxidant enzyme activity, sugar content and titratable acidity; however, the fruit developmental stage at the time of treatment was not clear and no statistical analysis was provided [47]. Blue light was also shown to increase sugar content in grapes, but in this case blue light treatment was initiated during early stages of fruit development where vines were treated for $3 \mathrm{~h}$ before sunrise and after sunset [20]. In contrast to our study, changes in fruit quality characteristics in the above studies may have been due to differences in the developmental stage at which treatments were initiated, as well as the duration and the intensity of treatments. 
In the present study, blue light treatment did not affect anthocyanin accumulation and other color-related parameters in 'Star' or 'Alapaha' blueberries harvested and treated at the ripe fruit stage. Furthermore, in 'Farthing' blueberries, treatment with blue light did not accelerate color development in the green spots at the stem-end. These results contrast with previous reports on strawberries and bayberries, which indicated that blue light can promote color development and anthocyanin accumulation with the activation of key enzymes involved in anthocyanin and flavonoid biosynthesis pathways $[28,48]$. However, in both of these studies, fruit were treated before ripening (based on surface coloration) was complete $[28,48]$. Similarly, in bilberries, which are closely related to blueberries, treatment with blue light at the green immature stage promoted anthocyanin accumulation in ripe fruit [29]. Thus, in the above studies, the developmental stage at which fruit were treated differed compared with the present study. Indeed, anthocyanin accumulation may not further increase in fruit after they have fully ripened. This argument is supported by a study in which blue light at $100 \mu \mathrm{mol} \mathrm{m} \mathrm{m}^{-2} \mathrm{~s}^{-1}$ initially promoted accumulation of anthocyanins in strawberries at an early developmental stage ( 25 days after flowering), until it reached a saturation point beyond which anthocyanin biosynthesis decreased [49]. In future studies, the effects of pre-harvest blue light treatments on fruit quality characteristics will need further evaluation.

In the present study we did not observe a consistent effect of blue light on natural disease incidence during postharvest storage, nor upon artificial inoculation with two common postharvest pathogens. For artificial inoculation, after 9-d light treatment post-inoculation, 'Star' and 'Alapaha' berries were placed at room temperature for $4 \mathrm{~d}$ under ambient light or the three light treatments, respectively. This duration of exposure at room temperature allows for infections that occurred before or during the blue light treatments to manifest. It is not likely that this duration is sufficient for new infections that occurred after transfer to room temperature to be displayed, as the typical incubation period for the pathogens tested here is one week or longer. Furthermore, a similar approach of transferring fruit to room temperature (in darkness) has been used previously in citrus studies [43].

Previous work in other systems suggests that blue light may have a retarding effect on the growth of certain postharvest disease fungi by increasing antioxidants, secondary metabolites having antimicrobial properties, and the expression of defense response genes [30,31]. In other cases, blue light directly suppressed mycelial growth or the activity of cell wall-degrading enzymes by postharvest fungi [32-35], suggesting the potential for multiple modes of action. In the above studies, the effect of disease progression after pathogen inoculation was assessed at $25^{\circ} \mathrm{C}$. However, in our study fruit were maintained at $4{ }^{\circ} \mathrm{C}$ after pathogen inoculation. Further, metabolic and/or gene interactions after pathogen infection may differ in blueberry fruit compared with the other host species studied previously.

Data from this study indicate that blue light is not more effective than dark or white light at maintaining blueberry fruit quality characteristics and limiting pathogen growth during cold storage. Additional research is needed to evaluate the effects of pre-harvest treatments with blue light on blueberry fruit quality. Further, the effects of varying intensities of blue light on postharvest blueberry fruit quality and disease development need to be investigated.

Supplementary Materials: The following are available online at http://www.mdpi.com/2311-7524/6/4/59/s1, Figure S1: Experimental set up depicting fruit placement in aluminum pans under light treatments. Figure S2: Images of 'Farthing' fruit at 0, 4, 8, and $11 \mathrm{~d}$ after light treatment (DAT).

Author Contributions: Conceptualization, Y-W.W., S.U.N., M.W.v.I., H.S. and H.D.L.; formal analysis, Y-W.W., S.U.N., H.D.C. and H.S.; funding acquisition, Savithri Nambeesan, M.W.v.I. and H.S.; investigation, Y.-W.W., S.U.N., M.W.v.I., H.S. and H.D.L.; methodology, M.W.v.I., H.S. and H.D.L.; project administration, S.U.N., M.W.v.I. and H.S.; resources, S.U.N., M.W.v.I. and H.S.; supervision, S.U.N., M.W.v.I. and H.S. All authors have read and agreed to the published version of the manuscript.

Funding: This project was partially funded by the Southern Region Small Fruit Consortium Project 2017 R-07.

Acknowledgments: We thank John W. Doyle for assisting with fruit collection and measurement of fruit quality attributes.

Conflicts of Interest: The authors declare no conflict of interest. The funding agency played no role in the design of the study, data collection and analysis, in preparing the manuscript and the decision to publish the results. 


\section{References}

1. Evans, E.; Ballen, F. An Overview of US Blueberry Production, Trade and Consumption, with Special Reference to Florida; University of Florida, IFAS, Extension: Gainesville, FL, USA, 2017.

2. Lang, G. A Southern highbush blueberries: Physiological and cultural factors important for optimal cropping of these complex hybrids. Acta Hortic. 1993, 346, 72-80. [CrossRef]

3. Rowland, L.J.; Ogden, E.L.; Bassil, N.; Buck, E.; McCallum, S.; Graham, J.; Brown, A.; Wiedow, C.; Campbell, A.M.; Haynes, K.G.; et al. Construction of a genetic linkage map of an interspecific diploid blueberry population and identification of QTL for chilling requirement and cold hardiness. Mol. Breed. 2014, 34, 2033-2048. [CrossRef]

4. Huang, W.-Y.; Zhang, H.-C.; Liu, W.-X.; Li, C.-Y. Survey of antioxidant capacity and phenolic composition of blueberry, blackberry and strawberry in Nanjing. J. Zhejiang Univ. Sci. B 2012, 13, 94-102. [CrossRef] [PubMed]

5. Basu, A.; Rhone, M.; Lyons, T.J. Berries emerging impact on cardiovascular health. Nutr. Rev. 2010, 68, 168-177. [CrossRef] [PubMed]

6. Neto, C.C. Cranberry and blueberry: Evidence for protective effects against cancer and vascular diseases. Mol. Nutr. Food Res. 2007, 51, 652-664. [CrossRef]

7. Abugoch, L.; Tapia, C.; Plasencia, D.; Pastor, A.; López, L.; Escalona, V.H.; Castro-Mandujano, O. Shelf-life of fresh blueberries coated with quinoa protein/chitosan/sunflower oil edible film. J. Sci. Food Agric. 2015, 96, 619-626. [CrossRef]

8. Almenar, E.; Samsudin, H.; Auras, R.; Harte, B.; Rubino, M. Postharvest shelf life extension of blueberries using a biodegradable package. Food Chem. 2008, 110, 120-127. [CrossRef]

9. Sun, X.; Narciso, J.; Wang, Z.; Ference, C.; Bai, J.; Zhou, K. Effects of Chitosan-Essential Oil Coatings on Safety and Quality of Fresh Blueberries. J. Food Sci. 2014, 79, M955-M960. [CrossRef]

10. Li, C.; Luo, J.; MacLean, D. A Novel Instrument to Delineate Varietal and Harvest Effects on Blueberry Fruit Texture During Storage. J. Sci. Food Agric. 2011, 91, 1653-1658. [CrossRef]

11. Mehra, L.K.; MacLean, D.D.; Savelle, A.T.; Scherm, H. Postharvest disease development on southern highbush blueberry fruit in relation to berry flesh type and harvest method. Plant Dis. 2013, 97, 213-221. [CrossRef]

12. Paniagua, A.; East, A.; Hindmarsh, J.; Heyes, J. Moisture loss is the major cause of firmness change during postharvest storage of blueberry. Postharvest Boil. Technol. 2013, 79, 13-19. [CrossRef]

13. Scherm, H.; Nesmith, D.S.; Horton, D.L.; Krewer, G. A Survey of Horticultural and Pest Management Practices of the Georgia Blueberry Industry. Small Fruits Rev. 2001, 1, 17-28. [CrossRef]

14. Chiabrando, V.; Giacalone, G. Quality evaluation of blueberries coated with chitosan and sodium alginate during postharvest storage. Intl. Food Res. J. 2017, 24, 1553-1561.

15. Nambeesan, S.U.; Doyle, J.; Capps, H.D.; Starns, C.; Scherm, H. Effect of Electronic Cold-Pasteurizationtm (ECPTM) on Fruit Quality and Postharvest Diseases During Blueberry Storage. Horticulturae 2018, 4, 25. [CrossRef]

16. Thang, K.; Au, K.; Rakovski, C.; Prakash, A. Effect of phytosanitary irradiation and methyl bromide fumigation on the physical, sensory, and microbiological quality of blueberries and sweet cherries. J. Sci. Food Agric. 2016, 96, 4382-4389. [CrossRef]

17. Trigo, M.; Sousa, M.; Sapata, M.; Ferreira, A.; Curado, T.; Andrada, L.; Ferreira, E.; Antunes, C.; Horta, M.; Pereira, A.; et al. Quality of gamma irradiated blueberries. Acta Hortic. 2006, 715, 573-578. [CrossRef]

18. Turtoi, M. Ultraviolet light treatment of fresh fruits and vegetables surface: A review. J. Agroaliment. Proc. Technol. 2013, 19, 325-337.

19. Kadomura-Ishikawa, Y.; Miyawaki, K.; Noji, S.; Takahashi, A. Phototropin 2 is involved in blue light-induced anthocyanin accumulation in Fragaria $x$ ananassa fruits. J. Plant Res. 2013, 126, 847-857. [CrossRef]

20. Kondo, S.; Tomiyama, H.; Rodyoung, A.; Okawa, K.; Ohara, H.; Sugaya, S.; Terahara, N.; Hirai, N. Abscisic acid metabolism and anthocyanin synthesis in grape skin are affected by light emitting diode (LED) irradiation at night. J. Plant Physiol. 2014, 171, 823-829. [CrossRef]

21. Braidot, E.; Petrussa, E.; Peresson, C.; Patui, S.; Bertolini, A.; Tubaro, F.; Wählby, U.; Coan, M.; Vianello, A.; Zancani, M. Low-intensity light cycles improve the quality of lamb's lettuce (Valerianella olitoria [L.] Pollich) during storage at low temperature. Postharvest Biol. Technol. 2014, 90, 15-23. [CrossRef] 
22. Costa, L.; Montano, Y.M.; Carrión, C.; Rolny, N.; Guiamet, J.J. Application of low intensity light pulses to delay postharvest senescence of Ocimum basilicum leaves. Postharvest Boil. Technol. 2013, 86, 181-191. [CrossRef]

23. Glowacz, M.; Mogren, L.M.; Reade, J.P.; Cobb, A.H.; Monaghan, J.M. High- but not low-intensity light leads to oxidative stress and quality loss of cold-stored baby leaf spinach. J. Sci. Food Agric. 2014, 95, 1821-1829. [CrossRef] [PubMed]

24. D'Souza, C.; Yuk, H.-G.; Khoo, G.H.; Zhou, W. Application of Light-Emitting Diodes in Food Production, Postharvest Preservation, and Microbiological Food Safety. Compr. Rev. Food Sci. Food Saf. 2015, 14, 719-740. [CrossRef]

25. Morrow, R.C. LED Lighting in Horticulture. HortScience 2008, 43, 1947-1950. [CrossRef]

26. Mitchell, C.A.; Both, A.-J.; Bourget, C.; Burr, J.; Kubota, C.; Lopez, R.; Morrow, R.; Runkle, E. LEDs: The future of greenhouse lighting! Chron. Hort. 2012, 52, 6-12.

27. Kopsell, D.A.; Sams, C.E.; Morrow, R.C. Blue Wavelengths from LED Lighting Increase Nutritionally Important Metabolites in Specialty Crops. HortScience 2015, 50, 1285-1288. [CrossRef]

28. Xu, F.; Cao, S.; Shi, L.; Chen, W.; Su, X.; Yang, Z. Blue Light Irradiation Affects Anthocyanin Content and Enzyme Activities Involved in Postharvest Strawberry Fruit. J. Agric. Food Chem. 2014, 62, 4778-4783. [CrossRef]

29. Zoratti, L.; Sarala, M.; Carvalho, E.; Karppinen, K.; Martens, S.; Giongo, L.; Häggman, H.; Jaakola, L. Monochromatic light increases anthocyanin content during fruit development in bilberry. BMC Plant Boil. 2014, 14, 377. [CrossRef]

30. Ahn, S.Y.; Kim, S.A.; Choi, S.-J.; Yun, H.K. Comparison of accumulation of stilbene compounds and stilbene related gene expression in two grape berries irradiated with different light sources. Hortic. Environ. Biotechnol. 2015, 56, 36-43. [CrossRef]

31. Kook, K.K.H.-S.; Kim, H.-S.K.K. The Effect of Blue-Light-Emitting Diodes on Antioxidant Properties and Resistance to Botrytis Cinerea in Tomato. J. Plant Pathol. Microbiol. 2013, 4, 203. [CrossRef]

32. Alferez, F.; Liao, H.-L.; Burns, J.K. Blue light alters infection by Penicillium digitatum in tangerines. Postharvest Boil. Technol. 2012, 63, 11-15. [CrossRef]

33. Barash, I.; Angel, E. Isolation and properties of an exopoly-galacturonase produced by Penicillium dsgitatum during infection of Lemon fruits. Israel J. Bot. 1970, 19, 599-608.

34. Barmore, C.R. Role of Pectolytic Enzymes and Galacturonic Acid in Citrus Fruit Decay Caused by Penicillium Digitatum. Phytopathol. 1979, 69, 675. [CrossRef]

35. Liao, H.-L.; Alferez, F.; Burns, J.K. Assessment of blue light treatments on citrus postharvest diseases. Postharvest Boil. Technol. 2013, 81, 81-88. [CrossRef]

36. Lee, J.; Durst, R.W.; Wrolstad, R.E.; Eisele, T.; Giusti, M.M.; Hofsommer, H.; Koswig, S.; Krueger, D.A.; Kupina, S.; Martin, S.K.; et al. Determination of Total Monomeric Anthocyanin Pigment Content of Fruit Juices, Beverages, Natural Colorants and Wines by the Ph Differential Method: Collaborative Study. J. AOAC Int. 2005, 88, 1269-1278. [CrossRef]

37. Campbell, C.L.; Madden, L.V. Introduction to Plant Disease Epidemiology; John Wiley \& Sons.: New York, NY, USA, 1990.

38. Barnett, H.L.; Hunter, B.B. Illustrated Genera of Imperfect Fungi, 4th ed.; American Phytopathological Society: St. Paul, MN, USA, 1998.

39. Wharton, P.; Schilder, A. Blueberry Fruit Rot Identification Guide; Michigan State University Extension: East Lansing, MI, USA, 2015.

40. Barnett, H.; Hunter, B.B. Illustrated Genera of Imperfect Fungi, 4th ed.; Macmillan Publishing Coy: New York, NY, USA; London, UK, 1987.

41. Cohen, Y.; Ben-Naim, Y.; Falach, L.; Rubin, A.E.; Rubin, A.E. Epidemiology of Basil Downy Mildew. Phytopathology 2017, 107, 1149-1160. [CrossRef]

42. Lee, Y.J.; Ha, J.Y.; Oh, J.E.; Cho, M.S. The effect of LED irradiation on the quality of cabbage stored at a low temperature. Food Sci. Biotechnol. 2014, 23, 1087-1093. [CrossRef]

43. Ballester, A.-R.; Lafuente, M.T. LED Blue Light-induced changes in phenolics and ethylene in citrus fruit: Implication in elicited resistance against Penicillium digitatum infection. Food Chem. 2017, 218, 575-583. [CrossRef] 
44. Yamaga, I.; Nakamura, S. Blue LED Irradiation Induces Scoparone Production in Wounded Satsuma Mandarin 'Aoshima Unshu' and Reduces Fruit Decay During Long-Term Storage. Hortic. J. 2018, 87, 474-480. [CrossRef]

45. Yamaga, I.; Takahashi, T.; Ishii, K.; Kato, M.; Kobayashi, Y. Suppression of Blue Mold Symptom Development in Satsuma Mandarin Fruits Treated by Low-Intensity Blue LED Irradiation. Food Sci. Technol. Res. 2015, 21, 347-351. [CrossRef]

46. Dhakal, R.; Baek, K.-H. Short period irradiation of single blue wavelength light extends the storage period of mature green tomatoes. Postharvest Boil. Technol. 2014, 90, 73-77. [CrossRef]

47. Xu, F.; Shi, L.; Chen, W.; Cao, S.; Su, X.; Yang, Z. Effect of blue light treatment on fruit quality, antioxidant enzymes and radical-scavenging activity in strawberry fruit. Sci. Hortic. 2014, 175, 181-186. [CrossRef]

48. Shi, L.; Cao, S.; Chen, W.; Yang, Z. Blue light induced anthocyanin accumulation and expression of associated genes in Chinese bayberry fruit. Sci. Hortic. 2014, 179, 98-102. [CrossRef]

49. Zhang, Y.; Jiang, L.; Li, Y.; Chen, Q.; Ye, Y.; Zhang, Y.; Luo, Y.; Sun, B.; Wang, X.; Tang, H.-R. Effect of Red and Blue Light on Anthocyanin Accumulation and Differential Gene Expression in Strawberry (Fragaria $\times$ ananassa). Molecules 2018, 23, 820. [CrossRef]

(C) 2020 by the authors. Licensee MDPI, Basel, Switzerland. This article is an open access article distributed under the terms and conditions of the Creative Commons Attribution (CC BY) license (http://creativecommons.org/licenses/by/4.0/). 